\title{
EVALUATION OF ANTIPYRETIC AND ANTIULCER ACTIVITY OF ETHANOLIC EXTRACT OF LEAVES OF ALSTONIA SCHOLARIS L. IN ALBINO WISTAR RATS
}

\author{
VANITA KANASE*, DEEPALI MANE
}

Department of Pharmacology, Oriental College of Pharmacy, Navi Mumbai, Maharashtra, India. Email: vanita.kanase@gmail.com

Received: 07 September 2019, Revised and Accepted: 14 October 2019

\section{ABSTRACT}

Objective: The purpose of the present study was aimed at evaluating the antipyretic and antiulcer activity on leaves of Alstonia scholaris L. (Family Apocynaceae) on albino Wistar rats. The antipyretic and antiulcer activity of the ethanolic extract of the A. scholaris L. leaves in three different concentrations $(50,100$, and $200 \mathrm{mg} / \mathrm{kg})$ were compared with standard paracetamol and pantoprazole, which was evaluated by employing brewer's yeast-induced pyrexia and ethanol-induced ulcer model. The biochemical parameters such as the volume of gastric juice secretion, $\mathrm{pH}$, total acidity, ulcer index, percentage protection, and lipid peroxidation (LPO) were also studied.

Methods: A. scholaris leaves were extracted with ethanol by Soxhlet extraction method. The dried extract was used for further phytochemical and pharmacological analysis. The antipyretic effect was studied using brewer's yeast-induced pyrexia. The ethanol-induced ulcer model was used to study the antiulcer effect.

Results: The percentage yield of ethanolic extract of $A$. scholaris leaves was $15.81 \% \mathrm{w} / \mathrm{w}$, respectively. The extract showed significant antipyretic and antiulcer effects when compared with standard paracetamol and pantoprazole.

Conclusion: The ethanolic extract of $A$. scholaris has significant antipyretic and antiulcer activity.

Keywords: Alstonia scholaris L., Antipyretic, Antiulcer activity, Ethanol-induced ulcer, ulcer index.

(C) 2019 The Authors. Published by Innovare Academic Sciences Pvt Ltd. This is an open access article under the CC BY license (http://creativecommons. org/licenses/by/4. 0/) DOI: http://dx.doi.org/10.22159/ajpcr.2019.v12i12.35630

\section{INTRODUCTION}

Peptic ulcers are one of the most common gastrointestinal diseases and widespread global problem in modern era arise due to various factors [1,2]. The pathophysiology of peptic ulcer disease has centered on an imbalance between aggressive and protective factors in the stomach [3]. The peptic ulcer is characterized by an area of the gastrointestinal tract which has been damaged by gastric acid or pepsin [4]. Lifestyle and dietary changes are the most prominent causes of peptic ulcer and related acid peptic disease [5]. The exploding occurrence of peptic ulcer in the first half of $20^{\text {th }}$ century in the medical scene led to recommend it as an epidemiological illness, which was followed by a reducing range of incidence and finally vanished as a surgical medicinal condition. The reason for this decline is due to more effective acid suppression drugs such as $\mathrm{H}_{2}$ receptor blockers, proton pump inhibitor, and recognition of Helicobacter pylori [6].

As a result, more and more drugs, both herbal and synthetic are coming up presenting newer and better options for the treatment of peptic ulcer [7]. Alstonia scholaris L., belongs to the family Apocynaceae as shown in Figs. 1 and 2, found to be widely distributed throughout tropical regions of sub-Himalayan belt, West Bengal, Bihar, peninsular India, and Southeast Asia. The shrub is commonly known as "Saptaparni" or the "Devil tree." It is one of the most versatile medicinal plants as well as in pharmacologically as a traditional medicine [8]. It is used in the treatment of antiarthritic [9], anticonvulsant [10], antibacterial [11], antidiabetic [12], anti-inflammatory [13], antioxidant [14,15], antimicrobial [16], ameliorative [17], bronchodialatory [18], and hepatoprotective [19].

\section{METHODS}

\section{Animals}

Male albino Wistar rats (180-220 g) were used for the study. The animals were obtained from CPCSEA approved institute Bharat Serums and
Vaccines Limited, Thane West, Maharashtra 400604. The use of these animals and the study protocols were approved by CPCSEA recognized Institutional Animal Ethics Committee of Oriental College of Pharmacy under protocol no. OCP/IAEC/2018-19/04 titled "to evaluate antipyretic, and antiulcer activity of $A$. scholaris L. in albino Wistar rats." Thesis entitled "evaluation of anti-ulcer activity of selected herbal plant." Rats were kept at the animal house of Oriental College of Pharmacy, Sanpada, Navi Mumbai; in polypropylene cages, at $22 \pm 2^{\circ} \mathrm{C}$, with $12: 12 \mathrm{~h}$ dark: light cycle. They were provided with commercial rat feed and water given ad libitum.

\section{Drugs and chemicals}

Paracetamol and pantoprazole were obtained from Cipla Ltd., and ethanol was obtained from Thomas Baker Chemicals, Brewer's yeast powder (Now Foods). All other chemicals used in this study were obtained commercially and were of analytical grade.

\section{Plant material}

The fresh leaves of $A$. scholaris L. were collected from near Seawoods station, Seawoods West, Mumbai, in October 2017 and were submitted to Dr. Rajendra D. Shinde, Director, Blatter Herbarium of St. Xavier's College, Mumbai. The leaves were compared and authenticated by comparison with the Blatter Herbarium Specimen No. NI-1417 of N.A. Irani.

\section{Qualitative phytochemical screening}

Preliminary chemical tests were carried out on the ethanolic extract of A. scholaris L. for determination of the presence of different phytoconstituents. All tests were performed by the procedures given in "Practical Pharmacognosy" by Dr. K. R. Khandelwal [20]. The result was shown in Tables 1 and 2.

\section{Selection of doses}

In literature survey, it was found that the ethanolic extract of $A$. scholaris $\mathrm{L}$. was safe. $\mathrm{LD}_{50}$ of the ethanolic extract is reported to be $2000 \mathrm{mg} / \mathrm{kg}$ [21]. The plant is often eaten by animals, which is also an indicator to prove 
it is less toxic. After thorough survey of various research papers, it is concluded that the final doses for the study are 50,100 , and $200 \mathrm{mg} / \mathrm{kg}$.

\section{Antipyretic study}

Brewer's yeast induced pyrexia model in one of the common models for induction of pyrexia. This model was used by various researchers such as Gupta et al. 2011I, Akapa et al. 2014, and Dewan et al. 2000 [22-24]. Yeast is able to produce the pyrogens in the body, causing generation of immune response, thus ultimately leading to the synthesis and release of prostaglandins, which is the final fever mediator in the brain, particularly in the preoptic area of the anterior hypothalamus.

The animals were divided into five groups (six animals in each group) for antipyretic studies.

\begin{tabular}{lll}
\hline Groups & Test substance & $\begin{array}{l}\text { Total no. } \\
\text { of animal }\end{array}$ \\
\hline Group I (negative) & 20\% yeast suspension & 6 \\
Group II (standard) & Paracetamol $150 \mathrm{mg} / \mathrm{kg}$ & 6 \\
Group III (test 1) & EEAS $150 \mathrm{mg} / \mathrm{kg}$ & 6 \\
Group IV (test 2) & EEAS $100 \mathrm{mg} / \mathrm{kg}$ & 6 \\
Group V (test 3) & EEAS $200 \mathrm{mg} / \mathrm{kg}$ & 6 \\
\hline
\end{tabular}

\section{Procedure [25-28]}

The normal body temperature of each rat was measured rectally and recorded. Pyrexia was induced by injecting $10 \mathrm{ml} / \mathrm{kg}$ body weight of $20 \%$ brewer's yeast suspension in saline solution into the subcutaneous route. Hick's digital thermometer coated with the lubricant was inserted 3-4 cm deep into the rectum and the basal temperature was recorded. After $18 \mathrm{~h}$ of yeast injection, each group receives the respective oral dosage of control/standard/test drug.

The temperature was recorded at 30,60, 90, 120,150, and $300 \mathrm{~min}$ after yeast injection. The result was shown in Table 3 and Fig. 3. Rectal temperature before and after treatment was compared and the percentage change in rectal temperature was calculated by the following formula:

Percent inhibition of rectal temperature $=$

$\left(\begin{array}{l}\text { Temperature at time " } \mathrm{t} \text { " } \\ \text { Initial temperature }\end{array}\right) \times 100$

Behavioral changes before and after injection of yeast suspension were also monitored.

\section{Anti ulcer study}

Ethanol-induced gastric ulcer model

Ethanol-induced gastric ulcer model is used on rats and is one of the widely used models due to its principle involving the cytoprotective action. Ethanol causes damage to the superficial epithelial layers, as well as is known to inhibit the prostaglandin release. It also increases the concentration of blood neutrophils, causing microcirculatory abnormality and generation of reactive oxygen species, leading to activation of $\mathrm{H}^{+} / \mathrm{K}^{+}$ATPase, i.e. proton pump, which leads to acid hypersecretion causing damage to GI mucosa [29].

Pantoprazole is widely used, one of the most commonly used drugs to treat gastric ulcers. It belongs to the class of proton pump inhibitors, which is the end step in the secretion of gastric acid. Proton pump inhibitors are prodrugs, which underwent sulfonamide cation form and irreversibly binds to the sulfhydryl group of $\mathrm{H}^{+} / \mathrm{K}^{+}$ATPase, causing complete inhibition of the acid secretion [30]. It also provides this activity on nocturnal acid secretion [31]. Any chemical agent that prevents the ethanol-induced ulcers might have the cytoprotective activity and may exert its action by stimulating the release of endogenous prostaglandins, as well as mucin. Similarly, this model can be used to screen possible anti-secretory activity effectively.

\section{Procedure [32-34]}

Ethanol-induced gastric ulcer method was done by the mechanism given by Oates and Hakkinen 1988 [32]. The ulcer was induced by ethanol 95\% (absolute ethanol). Male albino Wistar rats were divided into six groups. Six rats in each group, all groups were under a fasting state for $24 \mathrm{~h}$, but they were allowed to drink water. The purpose of fasting was to inhibit the cross-reaction of gastric content with administered treatments. All rats were orally given particular pre-treatment based on their groups and their weight. After $24 \mathrm{~h}$, test groups 1,2 , and 3 were administered with ethanolic extract of Trema orientalis L. leaves $(100,200$, and $3000 \mathrm{mg} / \mathrm{kg}$, p.o.) and the standard group received pantoprazole $(20 \mathrm{mg} / \mathrm{kg}$, p.o.). The control group received vehicle (distilled water). Two hours after drug treatment, the animals were sacrificed in the $\mathrm{CO}_{2}$ chamber and dissected to extract their stomach. Stomachs are cut open along the greater curvature and content of the stomachs was collected in test tubes for evaluation of gastric volume, total acidity, LPO, and $\mathrm{pH}$. Then, stomachs were gently rinsed with $0.9 \%$ saline solution and mounted on the wax plate. The result of ulcer index and percent protection was shown in Table 4 and Fig. 4.

Determination volume of gastric content, total acidity, and $\mathrm{pH}[35,36]$ Gastric contents of each rat were collected in the test tubes, and their volume was determined. To determine the $\mathrm{pH}, 1 \mathrm{ml}$ of distilled water is added to the $1 \mathrm{ml}$ aliquot of gastric juice. With the help of $\mathrm{pH}$ meter, the $\mathrm{pH}$ of the resultant solution was measured. To determine the total acidity, $1 \mathrm{ml}$ gastric juice was diluted by addition of $1 \mathrm{ml}$ distilled water.

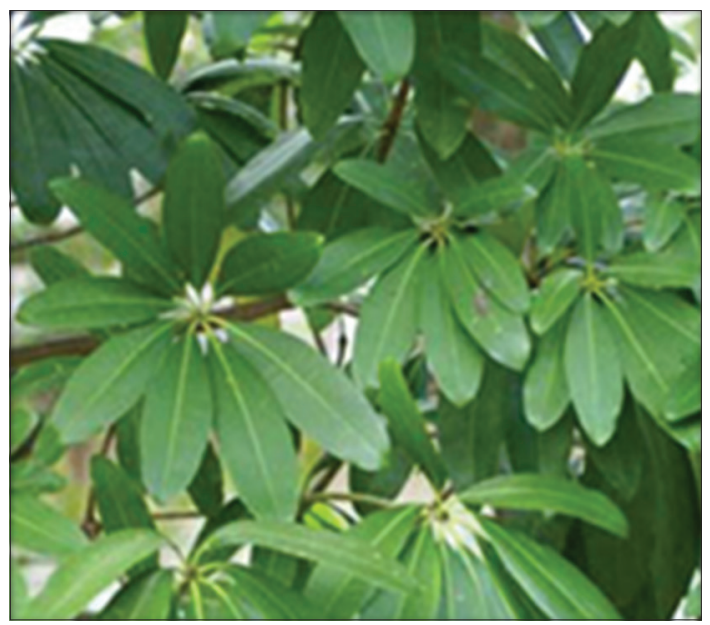

Fig. 1: Leaves of Alstonia scholaris

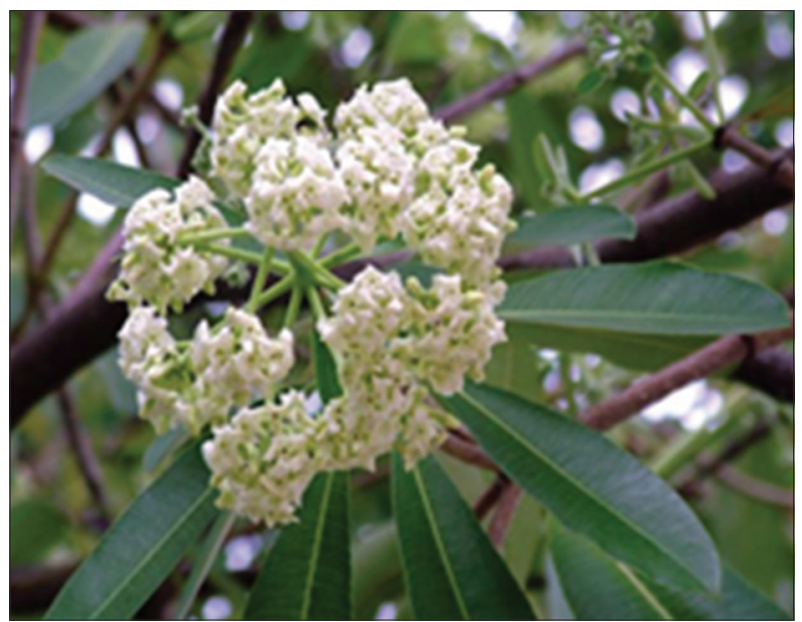

Fig. 2: Flower of Alstonia scholaris 
The resultant solution was transferred to the conical flask and titrated against the $0.01 \mathrm{~N} \mathrm{NaOH}$ with few drops of phenolphthalein solution as an indicator. The result was shown in Table 5 and Fig. 5. The total acidity was determined by the following formula:

$$
\text { Total acidity }=\left(\frac{\text { Vol. of } \mathrm{NaOH} \times 0.01}{0.1}\right) \times 100
$$

Evaluation of antiulcer activity

For determination of protection from the ulcer, ulcer index (UI) given by Ganguly and Bhatnagar (1973) was used, which is as follows [37,38]:

Normal colored stomach - (0), red coloration - (0.5), spot ulcer - (1), hemorrhagic streak - (1.5), deep ulcers - (2), perforation - (3)

UI was measured using following formula:

$$
\mathrm{UI}=(\mathrm{UN}+\mathrm{US}+\mathrm{UP}) \mathrm{X} 10^{-1}
$$

Where UI;

$\mathrm{UN}=$ Average number of ulcers per animal;

US = Average number of severity score;

$\mathrm{UP}=$ Percentage of animals with ulcers.

Similarly, from the data obtained after using the above equation, percent protection was determined using the following formula:

$$
\text { Percent protection }=\left(\frac{\text { UIa }- \text { UIt }}{\text { UIa }}\right) \times 100
$$

Where, UIa: UI of ulcer control group,

UIt: UI of test groups.

Furthermore, another method to determine the area of stomach affected by ulcer was suggested by Rathod et al. 2014, which requires the use of ImageJ Software [39]. Using this software, the total area of the antrum and the total ulcerated area was determined, and from this, percent protection was calculated with the following formula:

$$
\text { Percent protection }=\left(\frac{\mathrm{UAa}-\mathrm{UAt}}{\mathrm{UAa}}\right) \times 100
$$

Where, UAa: Ulcerated area of ulcer control group,

UAt: Ulcerated area of test groups.

Biochemical estimation of lipid peroxidation (LPO) from post mitochondrial supernatant (PMS) $[40,41]$

Procedure

Stomach was homogenized in chilled phosphate buffer ( $\mathrm{pH} 7.4$ ) using a homogenizer. The homogenates were centrifuged at $800 \mathrm{rpm}$ for $5 \mathrm{~min}$ at $4^{\circ} \mathrm{C}$ to separate the molecular debris. The supernatant so obtained was centrifuged at $10,000 \mathrm{rpm}$ for $20 \mathrm{~min}$ at $4^{\circ} \mathrm{C}$ to get the PMS.
$0.5 \mathrm{ml}$ of PMS was taken and it was added $0.5 \mathrm{ml}$ of tris hydrogen chloride buffer and incubated at $37^{\circ} \mathrm{C}$ for $2 \mathrm{~h}$, and then $1 \mathrm{ml}$ of icecold trichloroacetic acid was added and centrifuged at $1000 \mathrm{rpm}$ for $10 \mathrm{~min}$. From the above, $1 \mathrm{ml}$ of supernatant was taken and added $1 \mathrm{ml}$ of thiobarbituric acid and the tubes were kept in boiling water bath for $10 \mathrm{~min}$. The tubes were removed and brought up to room temperature and $1 \mathrm{ml}$ of distilled water was added. Absorbance was measured at $532 \mathrm{~nm}$ using an ultraviolet-visiblespectrophotometer. The result was shown in Table 6 and Fig. 6.

Blank

It was prepared without tissue homogenate.

$$
3 \times \frac{\text { Absorbance of sample }}{50.156 \times(\text { mg of tissuetaken })}=\mu \mathrm{m} / \mathrm{mg} \text { tissue }
$$

\section{Statistical analysis}

The data were analyzed with InStat Software by GraphPad (version 3.10). The results are expressed as the mean \pm SEM for each group. Statistical differences were evaluated using a one-way analysis of variance followed by Dunnett's t-test.

\section{RESULTS AND DISCUSSION}

\section{Physicochemical analysis of powdered leaves}

Table 1: Result of quantitative physicochemical analysis of powdered leaves of Alstonia scholaris L.

\begin{tabular}{lll}
\hline S. No. & Test & Result (\%) \\
\hline 1. & Water-soluble extractive value & 4 \\
2. & Ethanol soluble extractive value & 8 \\
3. & Chloroform soluble extractive value & 7 \\
4. & n-Hexane soluble extractive value & 2 \\
5. & Petroleum ether soluble extractive value & 2 \\
6. & Ethyl acetate & $4 \%$ \\
\hline
\end{tabular}

Qualitative phytochemical screening

Table 2: Result of quantitative phytochemical analysis of powdered leaves of $A$. scholaris $\mathrm{L}$.

\begin{tabular}{lll}
\hline $\begin{array}{l}\text { S. } \\
\text { No. }\end{array}$ & Phytoconstituents & $\begin{array}{l}\text { Ethanolic extract of the } \\
\text { leaves } \text { A. scholaris } \text { L. }\end{array}$ \\
\hline 1. & Alkaloids & + \\
2. & Flavonoids & + \\
3. & Cardiac glycosides & -- \\
4. & Saponins & + \\
5. & Steroids & + \\
6. & Terpenoids & + \\
7. & Tannins and phenolic compounds & + \\
\hline
\end{tabular}

+: Presence; --: Absence. A. scholaris: Alstonia scholaris

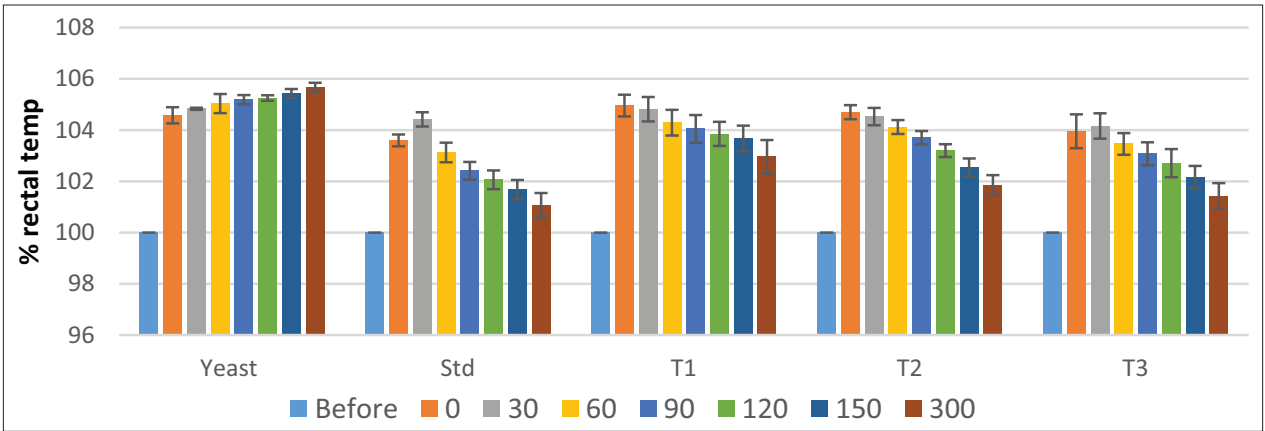

Fig. 3: Effect of ethanolic extract of Alstonia scholaris L. leaves on percent change in rectal temperature yeast-induced pyrexia in albino Wistar rats 
Table 3: Effect of ethanolic extract of Alstonia scholaris L. leaves on percent change in rectal temperature in yeast-induced pyrexia in albino wistar rats

\begin{tabular}{|c|c|c|c|c|c|c|c|}
\hline Group & $0 \mathrm{~min}$ & $30 \mathrm{~min}$ & $60 \mathrm{~min}$ & $90 \mathrm{~min}$ & $120 \mathrm{~min}$ & $150 \mathrm{~min}$ & $300 \mathrm{~min}$ \\
\hline $\begin{array}{l}\text { Yeast } \\
\text { control }\end{array}$ & $104.579 \pm 0.314$ & $104.831 \pm 0.040$ & $105.033 \pm 0.37^{\# \#}$ & $105.1852 \pm 0.18^{\# \#}$ & $105.2526 \pm 0.107^{\# \#}$ & $105.4209 \pm 0.180^{\# \#}$ & $105.673 \pm 0.170^{\# \#}$ \\
\hline Standard & $103.597 \pm 0.23$ & $104.417 \pm 0.28$ & $103.126 \pm 0.38^{* *}$ & $102.4097 \pm 0.35^{* *}$ & $102.0612 \pm 0.364^{* *}$ & $101.6776 \pm 0.375^{* *}$ & $101.067 \pm 0.477^{* *}$ \\
\hline $\begin{array}{l}\text { Test } 1 \\
\text { (EEAS } 50 \\
\mathrm{mg} / \mathrm{kg})\end{array}$ & $104.952 \pm 0.42$ & $104.813 \pm 0.48$ & $104.287 \pm 0.50$ & $104.0419 \pm 0.54^{\#}$ & $103.8483 \pm 0.47^{* \# \#}$ & $103.6731 \pm 0.502^{* \# \#}$ & $102.955 \pm 0.656^{* * \#}$ \\
\hline $\begin{array}{l}\text { Test } 2 \\
\text { (EEAS } 100 \\
\mathrm{mg} / \mathrm{kg} \text { ) }\end{array}$ & $104.697 \pm 0.28$ & $104.523 \pm 0.34$ & $104.121 \pm 0.27$ & $103.7027 \pm 0.26^{*}$ & $103.1965 \pm 0.251^{* *}$ & $102.534 \pm 0.358^{* *}$ & $101.853 \pm 0.387^{* *}$ \\
\hline $\begin{array}{l}\text { Test } 3 \\
\text { (EEAS } 200 \\
\mathrm{mg} / \mathrm{kg} \text { ) }\end{array}$ & $103.954 \pm 0.66$ & $104.160 \pm 0.49$ & $103.458 \pm 0.42 *$ & $103.0738 \pm 0.45^{* *}$ & $102.7081 \pm 0.547^{* *}$ & $102.1629 \pm 0.437^{* *}$ & $101.428 \pm 0.503^{* *}$ \\
\hline
\end{tabular}

Table 4: Effect of ethanolic extract of Alstonia scholaris L. leaves on UI and percent ulcer in albino wistar rats

\begin{tabular}{|c|c|c|c|c|}
\hline Group & $\begin{array}{l}\text { UI } \\
\text { (Ganguly and Bhatnagar 1973) }\end{array}$ & $\begin{array}{l}\text { Percent } \\
\text { protection }\end{array}$ & $\begin{array}{l}\text { Percent Ulcer } \\
\text { (ImageJ Software) }\end{array}$ & $\begin{array}{l}\text { Percent } \\
\text { protection }\end{array}$ \\
\hline Normal control & $0.00 \pm 0.000$ & - & - & - \\
\hline Ulcer control & $14.50 \pm 0.67$ & - & $18.48 \pm 3.26^{\# \#}$ & - \\
\hline Standard (pantoprazole) & $4.83 \pm 0.60$ & 66.33 & $0.41 \pm 0.12^{* *}$ & 99.59 \\
\hline Test 1 (50 mg/kg EEAS) & $9.24 \pm 0.34$ & 35.97 & $2.45 \pm 1.38^{* *}$ & 97.55 \\
\hline Test 2 (100 mg/kg EEAS) & $7.47 \pm 0.27$ & 48.21 & $1.10 \pm 0.99^{* *}$ & 98.90 \\
\hline Test 3 (200 mg/kg EEAS) & $5.87 \pm 0.19$ & 59.32 & $0.69 \pm 0.32^{* *}$ & 99.31 \\
\hline
\end{tabular}

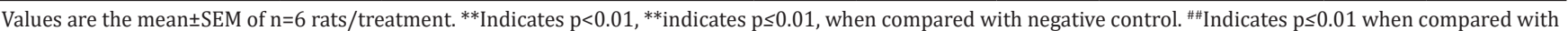
standard control. UI: Ulcer index

Table 5: Effect of ethanolic extract of Alstonia scholaris L. leaves on gastric volume, total acidity and pH of gastric juice in albino wistar rats

\begin{tabular}{lll}
\hline Group & Gastric volume (ml/100 g) & Total acidity (mEq/L) \\
\hline Normal control & $2.10 \pm 0.19^{* *}$ & $14.53 \pm 0.63^{* * \# \#}$ \\
Alcohol control & $3.93 \pm 0.25^{\#}$ & $20.04 \pm 0.56^{\# \#}$ \\
Standard (pantoprazole) & $2.43 \pm 0.40^{*}$ & $7.82 \pm 0.30^{* *}$ \\
Test 1 (50 mg/kg EEAS) & $2.04 \pm 0.62^{* *}$ & $12.82 \pm 0.30^{* * \# \#}$ \\
Test 2 (100 mg/kg EEAS) & $2.35 \pm 0.14^{*}$ & $1.01 \pm 0.15^{* * \# \#}$ \\
Test $3(200 \mathrm{mg} / \mathrm{kg}$ EEAS) & $2.18 \pm 0.23^{* *}$ & $6.00 \pm 0.14^{* * \#}$ \\
\hline
\end{tabular}

Values are the mean \pm SEM of $n=6$ rats/treatment. ${ }^{* *}$ Indicates $\mathrm{p}<0.01,{ }^{*}$ indicates $\mathrm{p} \leq 0$, when compared with negative control. ${ }^{\# \# I n d i c a t e s} \mathrm{p} \leq 0.01,{ }^{*}$ indicates $\mathrm{p} \leq 0$ when compared with standard control

\section{Antipyretic study}

All three test groups of the ethanolic extract of leaves of Alstonia scholars L. showed dose-dependent decrease in body temperature when compared against control as well as against paracetamol (standard).

\section{Antiulcer studies}

All the three test doses of the ethanolic extract of leaves of $A$. scholaris $\mathrm{L}$. showed dose-dependent decrease in UI when it was compared against control as well as against pantoprazole which was used as a standard.

\section{LPO}

Table 6: Effect of ethanolic extract of Alstonia scholaris L. leaves on LPO in albino wistar rats

\begin{tabular}{lll}
\hline S. No. & Treatment & Lipid peroxidation \\
\hline 1. & Normal control & $2.30 \pm 0.38$ \\
2. & Alcohol control & $2.64 \pm 0.14^{\#}$ \\
3. & Standard (pantoprazole) & $1.83 \pm 0.13^{*}$ \\
4. & Test $1(50 \mathrm{mg} / \mathrm{kg}$ EEAS) & $1.72 \pm 0.07^{* *}$ \\
5. & Test $2(100 \mathrm{mg} / \mathrm{kg}$ EEAS) & $1.32 \pm 0.09^{* *}$ \\
6. & Test $3(200 \mathrm{mg} / \mathrm{kg}$ EEAS) & $0.77 \pm 0.17^{* * \# \#}$ \\
\hline
\end{tabular}

Values are the mean \pm SEM of $n=6$ rats/treatment. ${ }^{* *}$ Indicates $p \leq 0.01,{ }^{*}$ indicates $\mathrm{p} \leq 0$ when compared with negative control when compared with standard.

Significance $\#$ p $\leq 0.01, \# \mathrm{p} \leq 0.05$

\section{DISCUSSION}

A. scholaris showed the inhibition of the increase in paw volume, as well as rectal temperature in albino Wistar rats in dose-dependent manner, it can be due to inhibition of inflammatory mediators such as cyclooxygenase, interleukins, or prostaglandins.

Ethanol produces massive intracellular accumulation of calcium, which represents a major step in the pathogenesis of gastric mucosal injury. This leads to cell death and exfoliation in the surface epithelium. Ethanol also acts on mitogen-activated protein kinase-II to release inflammatory mediators, which ultimately causes the mucosal injury. The antiulcer property of $A$. scholaris in ethanol-induced ulcer model is evident from its significant reduction in total acidity, gastric volume, $\mathrm{pH}, \mathrm{LPO}$, number of ulcers, and UI.

The preliminary phytochemical analysis of $A$. scholaris extract showed the presence of alkaloids, flavonoids, triterpenoids, carbohydrates, and glycosides. The significant increase in the antiulcer activity of A. scholaris could be attributed to the presence of flavonoids, alkaloids, tannins, saponins, glycosides, and phenolic compounds. Flavonoids are among the cytoprotective materials for which antiulcerogenic efficacy has been extensively confirmed. The leaves and flowers of $A$. scholaris were reported ursolic acid. Ursolic acid was found to be having reducing the effect of ulcer. It is suggested that, these active compounds would 


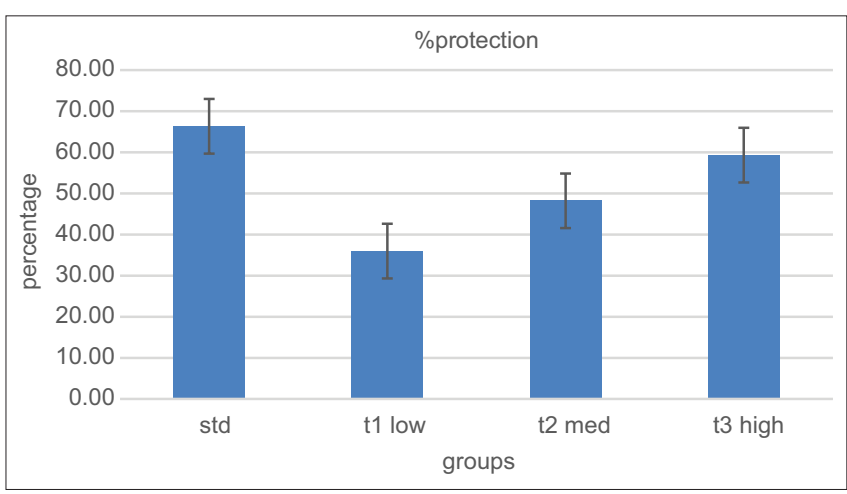

Fig. 4: Effect of ethanolic extract of Alstonia scholaris L. leaves on ulcer index and percent ulcer in albino Wistar rats

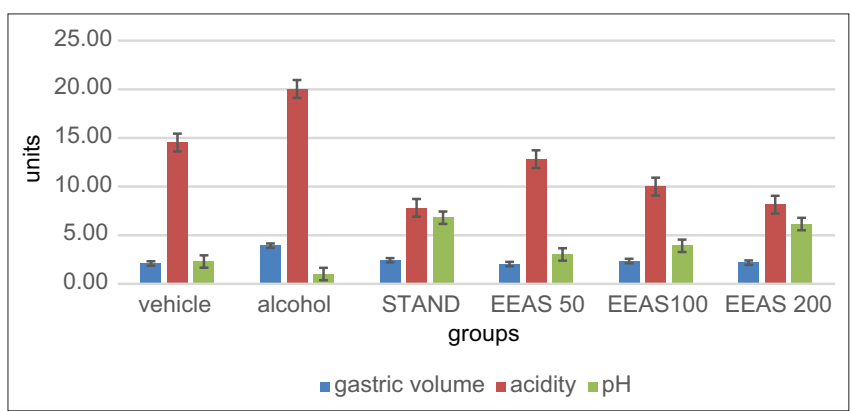

Fig. 5: Effect of ethanolic extract of Alstonia scholaris L. leaves on gastric volume, total acidity, and $\mathrm{pH}$ in albino Wistar rats. Significance ${ }^{* *} p \leq 0.01$, *indicates $p \leq 0.05$ when compared with negative control

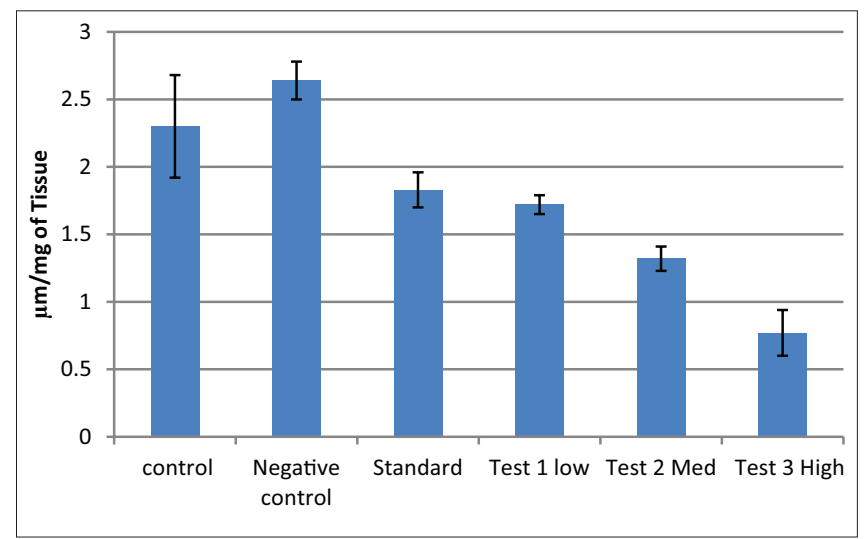

Fig. 6: Effect of ethanolic extract of Alstonia scholaris L. leaves on lipid peroxidation parameter in albino Wistar rats

be able to stimulate mucus, bicarbonate, and prostaglandin secretion and counteract with the deteriorating effects of reactive oxidants in gastrointestinal lumen. Hence, the antiulcer activity of $A$. scholaris may be attributed to its flavonoids content.

The results of the present study suggest that the methanol extract of A. scholaris leaves may be beneficial in the treatment of gastric ulcer induced by aggressive factors. Further studies to identify the active moieties and elucidation of the mechanism of action are recommended.

\section{CONCLUSION}

The present study does confirm that the ethanolic extract of $A$. scholaris does exhibit significant dose-dependent antipyretic and anti-ulcer activity. The bioactivity-guided phytochemical screening of ethanolic extract of $A$. scholaris revealed the presence of flavonoids, tannins, and triterpenoids, which may be responsible for the anti-ulcer effect and can be further fractionated and investigated for their role and utility in any of the anti-ulcer mechanisms.

\section{AUTHORS' CONTRIBUTIONS}

We declare that this work was done by the authors named in this article and all liabilities pertaining to claims relating to the content of this article will be borne by the authors. Miss Deepali Mane collected the data and analyzed the data Dr. (Mrs.) Vanita Kanase proofread the whole manuscript, and suggested the necessary changes, and helps in designing manuscript.

\section{CONFLICTS OF INTEREST}

The authors declare that there are no conflicts of interest regarding the publication of this paper.

\section{REFERENCES}

1. Elumalai A, Naresh V, Eswaraiah MC, Narendar P, Kumar R. Evaluation of antiulcer activity of Couroupita guianensis Aubl leaves. Asian J Pharm Tech 2012;2:64-6.

2. Pandey D, Joshi A, Hemalatha S. Anti-ulcer study of standardized ethanol root extract of Aganosma dichotoma and isolated ursolic acid. Int J Pharm Pharm Sci 2017;9:172.

3. Mahurkar N, Ul Hasan SM, Malpani AA, Chetan M. Influence of single and multiple dose regimen of melatonin, rabeprazole and their combination in gastroprotection in pylorus ligated albino rats. Res J Pharm Tech 2013;6:562-8.

4. Harbison S, Dempsey D. Peptic ulcer disease. Curr Prob Surg 2005;42:346-454.

5. Singh J, Gowda KP, Badami S, Akuskar R, Tukuru N. Scrutinizing the fresh juice of leaves of Pedalium murex for the antiulcer activity in rats. Res J Pharm Tech 2009;2:191-4.

6. Gustafson J, Welling D. "No acid, no ulcer"--100 years later: A review of the history of peptic ulcer disease. J Am Coll Surg 2010;210:110-6.

7. Rai U, Pattnaik AK, Singh S. Antiulcer activity of the most active subfraction of methanolic leaf extract of Buchanania lanzan Spreng. Int J Pharm Pharm Sci 2016;8:93-101.

8. Pankti K, Payal G, Manodeep C, Jagadish K. A phytopharmacological review of Alstonia scholaris: A panoramic herbal medicine. Int J Res Ayurveda Pharm 2012;3:367-71.

9. Arulmozhi S, Mazumder PM, Lohidasan S, Ashok P. Anti arthritic and antioxidant activity of leaves of Alstonia scholaris L.R. Br. Eur J Intigrat Med 2011;3:e83-90.

10. Quazi JA. Evaluation of possible anticonvulsant effect of Alstonia scholaris (Linn.) R. Br. Extract on epilepsy models. Asian J Pharm Clin Res 2015;8:207-9.

11. Kachhawa JB, Sharma N, Tyagi S, Gupta RS, Sharma KK. Antibacterial activity of Alstonia scholaris: An in vitro study. Int J Pharm Sci Rev Res 2012;12:40-1.

12. Arulmozhi S, Mazumder PM, Lohidasan S, Thakurdesai P. Anti dibetic and antihyperlipidemic activity of leaves of Alstonia scholaris L.R. Br. Eur J Intigrat Med 2010;2:23-32.

13. Subraya CK, Harikiran, Gupta D. Antioxidant and anti-inflammatory activity of Alstonia scholaris R.Br. stem bark extract. Free Radic Antioxid 2012;2:55-7.

14. Arulmozhi S, Mazumder PM, Narayanan LS, Thakurdesai PA. In vitro antioxidant and free radical scavenging activity of fractions from Alstonia scholaris Linn. R. Br Int J PharmTech Res 2010;2:18-25.

15. Dhruti M, Bhavika P, Meonis P. Studies on phytochemical constituents and antioxidant activity of Alstonia scholaris. Int $\mathrm{J}$ Life Sci 2016;4:529-38.

16. Madan H, Gogia S, Sharma S. Antimicrobial and spermicidal activities of Parthenium hysterophorus Linn. And Alstonia scholaris Linn. Indian J Nat Prod Resourc 2011;2:458-63.

17. Singh H, Arora R, Arora S, Singh B. Ameliorative potential of Alstonia scholaris (Linn.) R. Br. Against chronic constriction injury-induced neuropathic pain in rats. BMC Complement Altern Med 2017;17:63.

18. Channa S, Dar A, Ahmed S, Atta-ur-Rahman. Evaluation of Alstonia scholaris leaves for broncho-vasodilatory activity. J Ethnopharmacol 2005;97:469-76.

19. Lin SC, Lin CC, Lin YH, Supriyatna S, Pan SL. The protective effect of Alstonia scholaris $\mathrm{R}$. Br. On hepatotoxin-induced acute liver damage. Am J Chin Med 1996;24:153-64. 
20. Khandelwal K. Practical Pharmacognosy. Maharashtra: Nirali Prakashan; 2008.

21. Jash R, Chowdary KA. Ethanolic extracts of alstonia scholaris and bacopa monniera possess neuroleptic activity due to anti-dopaminergic effect. Pharmacognosy Res 2014;6:46-51

22. Hossain E, Mandal SC, Gupta JK. Phytochemical screening and in-vivo antipyretic activity of the methanol leaf-extract of Bombax malabaricum DC (Bombacaceae). Trop J Pharm Res 2011;10:55-60.

23. Akapa TC, Kehinde AO, Beatrice OO, Joseph O. Antipyretic activity of Abutilon mauritianum (Jacq.) roots in Wistar rats. Int J Pharm Sci Res 2014;5:42-6.

24. Dewan S, Suresh K, Kumar VL. Antipyretic effect of latex of Calotropis procera. Indian J Pharmacol 2000;32:252.

25. Loux JJ, DePalma PD, Yankell SL. Antipyretic testing of aspirin in rats. Toxicol Appl Pharmacol 1972;22:672-5.

26. Sathish R, Kumar PS, Natarajan K, Sridhar N. Hepatoprotective and anti pyretic activities of methanolic extract of Butea monosperma Lam stem bark in Wister rats. Asian J Pharm Res 2011;1:130-3.

27. Valli G, Vijayalakshmi R, Vasanthi A, ThangaThirupathi A. Studies of antipyretic and anti-inflammatory activities of odina woodier leaves extracts. Res J Pharmacol Pharmacodyn 2011;3:263-7.

28. Patil SB, Chavan GM, Ghodke DS, Naikwade NS, Magdum CS. Screening of some indigenous plants for their antipyretic activity. Res J Pharmacol Pharmacodyn 2009; 1:143-4

29. Kaur M, Singh A, Kumar B. Comparative antidiarrheal and antiulcer effect of the aqueous and ethanolic stem bark extracts of Tinospora cordifolia in rats. J Adv Pharm Technol Res 2014;5:122-8.

30. Parsons ME. Pantoprazole, a new proton-pump inhibitor, has a precise and predictable profile of activity. Eur J Gastroenterol Hepatol 1996;8 Suppl 1:S15-20.
31. Shin JM, Sachs G. Pharmacology of proton pump inhibitors. Curr Gastroenterol Rep 2008;10:528-34.

32. Oates PJ, Hakkinen JP. Studies on the mechanism of ethanol-induced gastric damage in rats. Gastroenterology 1988;94:10-21.

33. Rathnakumar K, Jaikumar S, Sengottuvelu S. Antiulcer activity of Euphorbia hirta against experimentally induced ulcer in rats. Asian J Pharm Res 2013;3:122-4.

34. Girish C, Vineela S, NarasimhaReddy Y, Reddy OV, Rajasekhar KK, Shankarananth V. Evaluation of antiulcer activity of Coccinia grandis leaves. Res J Pharmacol Pharmacodyn 2011;3:92-5.

35. Kumar V, Bhat Z, Kumar D, Khan N, Chashoo I, Ara I. Gastroprotective effect of leafextracts of Basella alba var. Alba against experimental gastric ulcers in rats. Rev Bras Farmacogn 2012;22:657-62.

36. Divakar M, Devi S. Antiulcer activity of Wrightia tinctoria (Roxb.) R. Br. Der Pharm Sin 2018;2:355-60.

37. Ganguly AK, Bhatnagar OP. Effect of bilateral adrenalectomy on production of restraint ulcers in the stomach of albino rats. Can $\mathrm{J}$ Physiol Pharmacol 1973;51:748-50.

38. Malairajan P, Gopalakrishnan G, Narasimhan S, Veni KJ, Kavimani S. Anti-ulcer activity of crude alcoholic extract of Toona ciliata Roemer (heart wood). J Ethnopharmacol 2007;110:348-51.

39. Rathod S, Motghare V, Deshmukh V. Study of antiulcer activity of angiotensin receptor antagonists in experimentally induced gastric ulcers in rats. Int J Pharm Sci Res 2014;5:502-7.

40. DharmaSwathi KV, Prasad G. Antioxidant and antiulcer potential of ethanolic extract of bark of Myrica esculenta in pyloric ligation ulcer model. Int J Pharm Pharm Sci 2015;7:195-8.

41. Ghaisas MM, Sharma S, Ganu GP, Limaye RP. Antiulcer activity of Colebrookea oppositifolia Sm. Res J Pharmacol Pharmacodyn 2010;2:66-70 